\title{
Frequency distributions of mean daily intakes of food energy and selected nutrients obtained during nutrition surveys of different groups of people in Great Britain between 1968 and 1971
}

\author{
BY SYLVIA J. DARKE, MOLLY M. DISSELDUFF AND G. P. TRY \\ Department of Health and Social Security, Alexander Fleming House, Elephant and Castle, \\ London $S E_{1} 6 B Y$
}

(Received 30 April 1980 - Accepted 30 May 1980)

\begin{abstract}
1. Nutrition surveys were made in Great Britain between 1968 and 1971 of 1321 pre-schoolchildren aged 6 months to 4.5 years, 321 primary schoolchildren (IO-I I years), 178 secondary schoolchildren (I4-I 5 years), 792 secondary schoolchildren (14-15 years), 435 women in the second trimester of pregnancy, 443 elderly people (65-74 years), 384 elderly people ( 75 years and over).

2. The studies included a $7 \mathrm{~d}$ weighed dietary record and all subjects except some of the pre-schoolchildren were medically assessed for evidence of malnutrition. Among the children there were no clinical signs of undernutrition, $4 \%$ of the boys and $7 \%$ of the girls were described as obese. In the survey of elderly people $3 \%$ were malnourished but in each case malnutrition was associated with clinical disease.

3. Percentage frequency distribution curves of mean daily intakes (averaged for $7 \mathrm{~d}$ ) were obtained for total food energy, total protein, animal protein, fat, carbohydrate, calcium, iron, retinol, thiamin, riboflavin, nicotinic acid, pyridoxine, vitamin $C$ and vitamin $D$.

4. Comparison of the distribution of food energy intakes with 1969 recommendations (Department of Health and Social Security, 1969) showed that the mean of the distribution was less than the 1969 recommendation for energy. From the age of 12 months, results indicated that males had larger intakes of food energy than females.

5. Comparison of the distributions for protein, $\mathrm{Ca}, \mathrm{Fe}$, retinol, thiamin, riboflavin and vitamin $\mathrm{C}$ with the recommendations for these nutrients revealed that appreciable numbers of people had intakes less than the recommendations without signs of malnutrition.
\end{abstract}

There have been few published results from recent nutrition studies of population groups of any size in the United Kingdom apart from a study of pre-schoolchildren in Newcastleupon-Tyne (Black et al. 1976), a survey of Kent schoolchildren aged 8-15 years (Topp et al. 1972), studies of schoolchildren in Glasgow aged I4 years (Durnin et al. 1964; Durnin et al. 1974) and of smaller groups of elderly people (Stanton \& Exton-Smith, 1970; Exton-Smith et al. 1972).

In I963 a study of 450 pre-schoolchildren aged 6 months-5 years (Ministry of Health, 1968) was made to test the method for a series of nutrition surveys of population groups in the United Kingdom. The main surveys (six in all) were made between 1968 and 197 I and were of people who could have been at risk of malnutrition. Some, but not all, have been reported (Department of Health and Social Security, 1972, 1975). In this paper, we present the centile distributions of mean daily intakes of food energy and of selected nutrients. These results may be of some use for purposes of comparison with similar measurements made at other times.

\section{EXPERIMENTAL}

\section{Subjects}

Pre-schoolchildren. In 1967-68, a sample of pre-schoolchildren aged 6 months -4.5 years was randomly selected from thirty-nine areas in Great Britain (Department of Health and Social Security, 1975). The areas were regarded as corporately representative of the country as a whole and dietary information was obtained from I 32 I children. 


\section{Sylvia J. Darke, Molly M. Disselduff and G. P. Try}

Primary schoolchildren. Between I January and 3I March 197I, a sample of boys and girls aged IO-I I years from primary schools in Bristol, Croydon and Sheffield was studied. In each of the three areas, three schools were chosen by the Principal School Medical Officer on the basis of his local knowledge as being likely to have the largest proportion of children whose parents' income was such that they would just not qualify for the benefit of free school meals. The samples were randomly selected from all children in the schools who were of the required age; 163 boys and $15^{8}$ girls took part.

Secondary schoolchildren Newcastle-upon-Tyne. A sample of schoolchildren aged 14-15 years who were from one-parent families in Newcastle-upon-Tyne was studied between February and July 1970 together with a control sample, matched for sex and month of birth, of children living with both parents. Information was obtained from ninety-three boys and eighty-five girls.

Secondary schoolchildren Birmingham. From I September 1970 to 31 August 1971, a study was made of schoolchildren aged 14-15 years who were randomly selected from all schools situated in the south-east area of Birmingham. This city was chosen as an example of a large industrial conurbation and the south-east postal district was selected because the area extended from the crowded city centre to the outer suburbs. Dietary information was obtained from 390 boys and 402 girls.

Pregnant women. In $1967-68$ a sample of 435 women who were 6-7 months pregnant was selected from thirty-nine areas in Great Britain. The sample was not nationally representative.

Elderly. A study of elderly people in 1967/68 included 396 men and 431 women who were living in their own homes or with relatives from four different areas in England and two in Scotland (Department of Health and Social Security, 1972). The subjects were all 65 years of age or over and in one area (the London borough of Camden) they were all 70 years or over.

\section{Methods}

All the studies were cross-sectional in design and the survey method has been described (Ministry of Health, 1968; Department of Health and Social Security, 1972, 1975). Trained dietary investigators visited each respondent in their own home in order to explain the purpose of the survey and to make periodic checks on the keeping of the dietary records. Full participation in a study yielded socio-economic information, and a weighed record of all food (solid and liquid) ingested for a period of seven consecutive days. A specially designed food composition table (available on request from Mrs M. M. Disselduff at the Department of Health and Social Security) was used in the surveys. The table identified over 600 food codes each of which had an attributed figure for energy value and certain nutrients. The mean daily intakes of food energy and nutrients were calculated for each individual from the weighed amounts of all food and drink consumed in the survey week.

Except for some pre-schoolchildren, all subjects were assessed medically for clinical signs of malnutrition and height, weight and skinfold measurements were made. In surveys of elderly people a blood sample was taken for biochemical and haematological analysis, and radiology of the metacarpal was done. The results of these findings are reported elsewhere.

\section{RESULTS}

\section{Medical assessment}

None of the children were described as of poor nutritional status, a few were described as fair but the large majority were assessed as of good nutritional status. Approximately $4 \%$ 


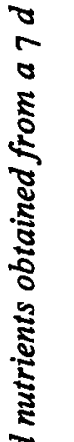

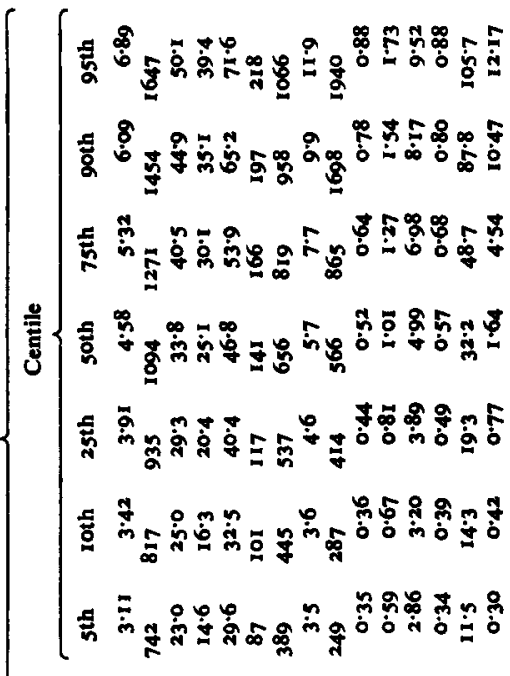

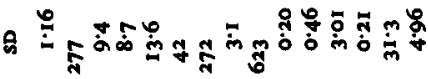

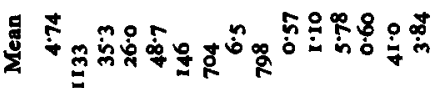

2.

定学

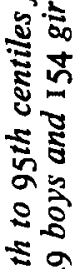

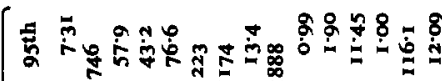

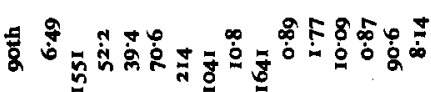

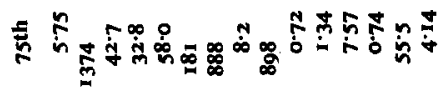

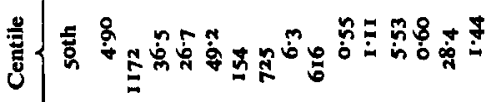

ปิ

ธี

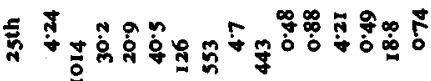

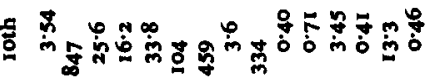

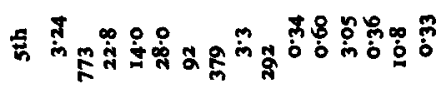

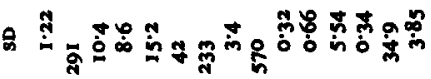

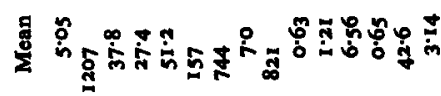

हूँ

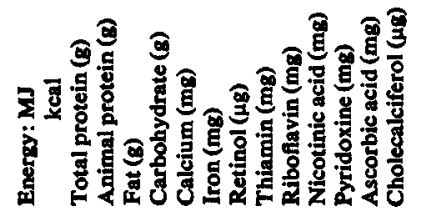


246 Sylvia J. Darke, Molly M. Disselduff and G. P. Try

ำ

छ̊⿻日禸

过

है:

赵

$\mathbb{D}^{2}$

5

$2 \frac{2}{2}$

कृष

है.

हू

䒽

हิ ใ้

है

है है

ํํㄴ

จู

5.

ปัँ

:

हิ

క

ह

हี

i

䒿

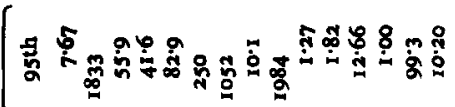

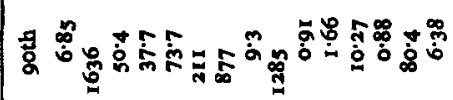

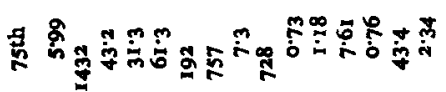

运

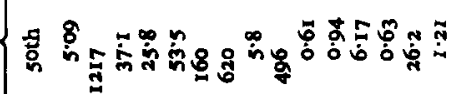

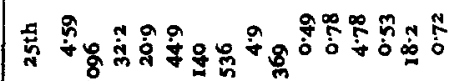

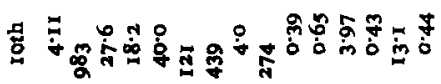

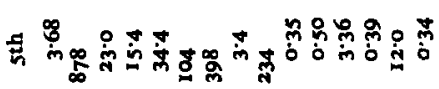

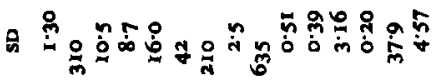

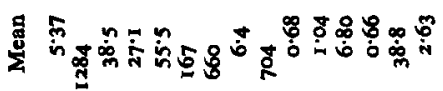

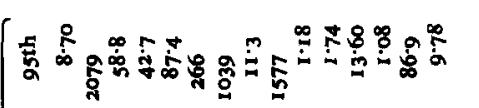

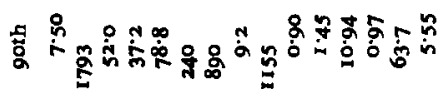

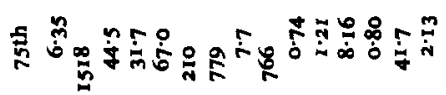

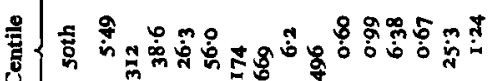

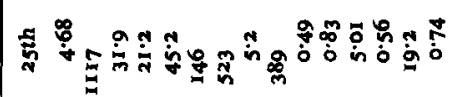

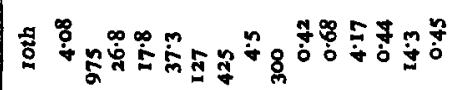

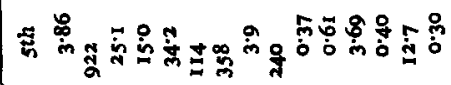

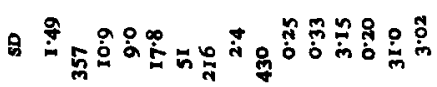

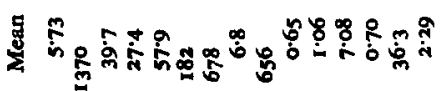

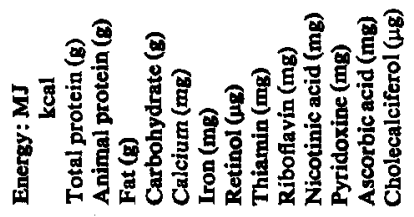

0
0
5
5
0
0
5
0

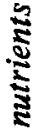

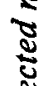

䒺

蛋

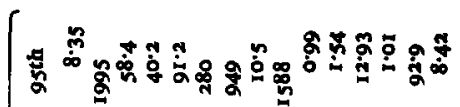

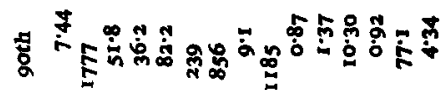

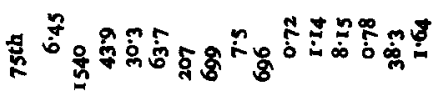

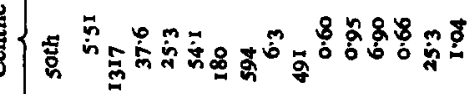

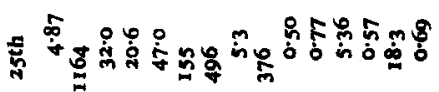

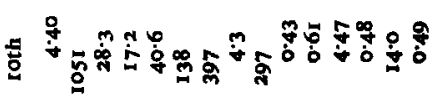

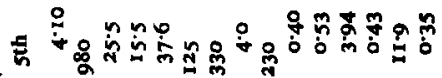

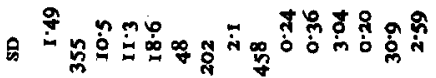

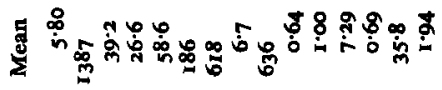

ऐัฒ

ำ

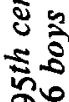

ลูำ

ปे

जิ

है

.ิ

\%

:

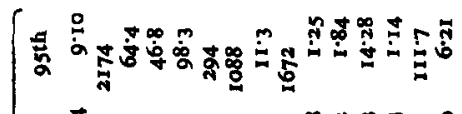

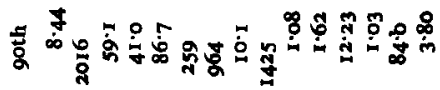

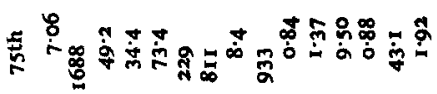

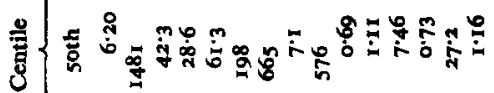

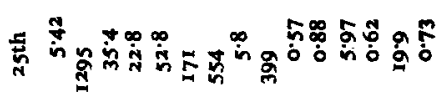

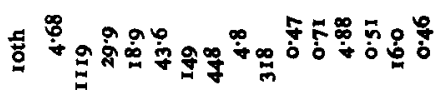

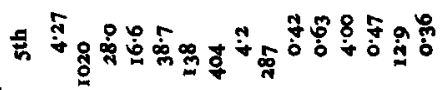

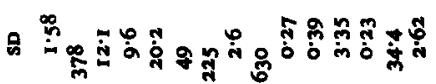

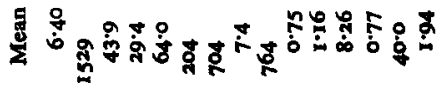

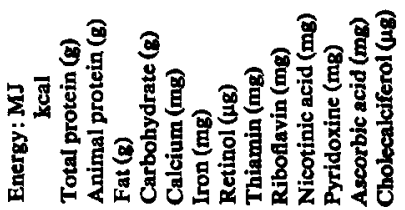


Table 4. The mean daily intake, standard deviation and 5 th to 95th centiles for total food energy and selected nutrients obtained from a $7 d$ weighed dietary study of 435 pregnant women in the 6 th-7th month of pregnancy in $1967-68$

Energy: MJ kcal

Total protein (g)

Animal protein (g)

Fat (g)

Carbohydrate (g)

Calcium (mg)

Iron (mg)

Retinol ( $\mu \mathrm{g})$

Thiamin (mg)

Riboflavin (mg)

Nicotinic acid (mg)

Pyridoxine (mg)

Ascorbic acid (mg)

Cholecalciferol ( $\mu \mathrm{g})$

\begin{tabular}{|c|c|c|c|c|c|c|c|c|}
\hline \multirow[b]{2}{*}{ Mean } & \multirow[b]{2}{*}{ SD } & \multicolumn{7}{|c|}{ Centile } \\
\hline & & 5th & Ioth & 25th & soth & 75th & goth & 95th \\
\hline $9 \cdot 01$ & $2 \cdot 10$ & 5.55 & $6 \cdot 35$ & 7.63 & 9.04 & 10.28 & $11 \cdot 60$ & 12.56 \\
\hline 2152 & 503 & 1325 & 1517 & 1822 & 2159 & 2456 & 2771 & 3000 \\
\hline 70.5 & 16.7 & 43.8 & $49 \cdot 6$ & $59 \cdot 0$ & $70 \cdot 3$ & 80.7 & $92 \cdot 3$ & 98.0 \\
\hline $47 \cdot 8$ & $14 \div 3$ & $26 \cdot 1$ & $3 I^{\circ} 0$ & $37 \cdot 5$ & $46 \cdot 8$ & 56.5 & $65 \cdot 6$ & $71 \cdot 7$ \\
\hline $97 \cdot 9$ & $26 \cdot 4$ & 55.7 & 65.1 & $80 \cdot 0$ & $96 \cdot 6$ & 113.2 & 130.6 & $14 I \cdot 2$ \\
\hline 260 & 69 & 143 & 172 & 211 & 264 & 304 & 344 & 370 \\
\hline 959 & 320 & 470 & 547 & 740 & 946 & 1168 & 1363 & I522 \\
\hline 117 & $3 \cdot 1$ & $6 \cdot 8$ & $8 \cdot 2$ & $9 \cdot 7$ & $11 \cdot 5$ & $13 \cdot 5$ & 15.4 & $17 \cdot 1$ \\
\hline 1269 & 975 & 424 & 516 & 679 & 961 & 1493 & 2485 & 2924 \\
\hline I.04 & 0.28 & 0.62 & 0.70 & 0.85 & 1.03 & $1 \cdot 20$ & $1 \cdot 38$ & I 47 \\
\hline $1 \cdot 60$ & 0.67 & 0.78 & 0.92 & $1 \cdot 14$ & $1 \cdot 5 I$ & 1.90 & $2 \cdot 30$ & $2 \cdot 54$ \\
\hline $\begin{array}{r}14 \cdot 30 \\
1 \cdot 27\end{array}$ & $\begin{array}{l}5.30 \\
0.32\end{array}$ & $\begin{array}{l}7.90 \\
0.74\end{array}$ & $\begin{array}{l}8.88 \\
0.88\end{array}$ & $\begin{array}{r}10.89 \\
1.08\end{array}$ & $\begin{array}{r}13.41 \\
1.24\end{array}$ & $\begin{array}{r}16.41 \\
I .45\end{array}$ & $\begin{array}{r}20.34 \\
1.66\end{array}$ & $\begin{array}{r}23.27 \\
1.80\end{array}$ \\
\hline $\begin{array}{c}54 \cdot 9 \\
2 \cdot 28\end{array}$ & $\begin{array}{c}24 \cdot 7 \\
2 \cdot 01\end{array}$ & $\begin{array}{c}22.7 \\
0.64\end{array}$ & $\begin{array}{c}28.0 \\
0.76\end{array}$ & $\begin{array}{c}37 \cdot 7 \\
I \cdot 12\end{array}$ & $\begin{array}{c}49.7 \\
1.66\end{array}$ & $\begin{array}{c}68 \cdot 2 \\
2 \cdot 54\end{array}$ & $\begin{array}{l}89 \cdot 0 \\
4.40\end{array}$ & $\begin{array}{c}102.3 \\
6.06\end{array}$ \\
\hline
\end{tabular}

of the boys and $7 \%$ of the girls were assessed as obese. No clinical signs of specific nutrient deficiencies were seen. The nutritional status of most of the elderly subjects was also satisfactory; a few (3\%) were malnourished but in each case this was due to co-existent clinical disease.

\section{Energy and nutrient intakes}

Tables $I-9$ show the fifth to the ninety-fifth centiles for the mean daily intakes of food energy by males and females separately in the different population groups. As early as I 2-23 months of age there was a statistically significant difference $(P<0.05)$ in the mean energy intake between the sexes; the mean energy intake of the boys being, as for older males, greater than that of the girls of the same age. The differences were more pronounced in the older age-groups.

Tables I-9 also show, for males and females separately in the different population groups, the fifth to the ninety-fifth centiles for the mean daily intakes of total protein, animal protein, fat, carbohydrate, calcium, iron, retinol, thiamin, riboflavin, nicotinic acid, pyridoxine, ascorbic acid and ergocalciferol.

\section{DISCUSSION}

The most important finding of the surveys was that none of the children studied showed clinical signs of undernutrition. Undernutrition, diagnosed in $3 \%$ of the elderly subjects, was associated with debilitating disease.

\section{Food energy intakes}

In general, except for pre-school boys and elderly men, the means of the distribution for each sample were lower than those recommended (Department of Health and Social Security, I 969) so that more than half the group had daily intakes which were less than the recommended amount. These findings confirm those for children under 4 years of age (Black et al. 1976); for schoolchildren aged 7-17 years in Kent (Cook et al. 1973); for schoolchildren aged 14 years in Glasgow (Durnin et al. 1974), and for the elderly (Exton- 
248 Sylvia J. Darke, Molly M. Disselduff and G. P. Try

ป

ב

品

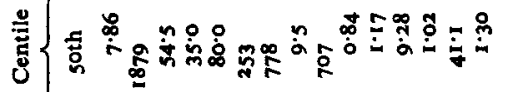

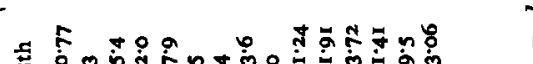

0
0
5
5
0
0
0
0

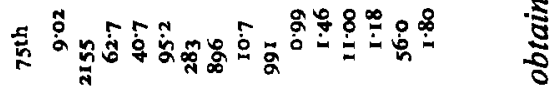

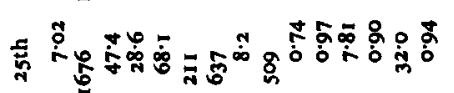

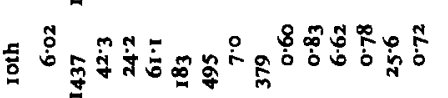

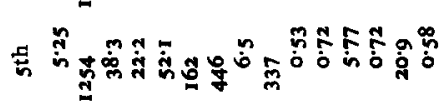

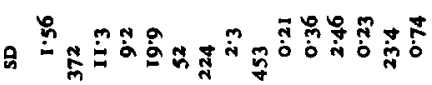

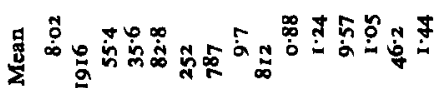

ฐ

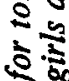

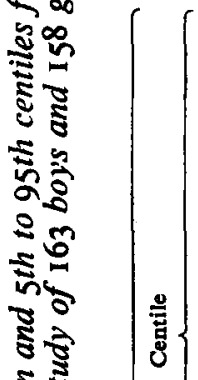

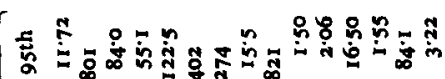

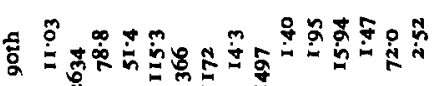

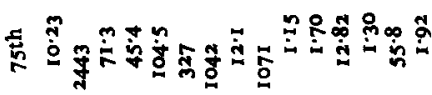

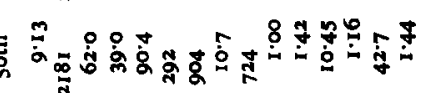

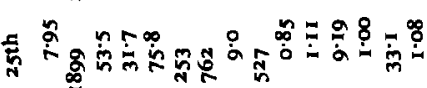

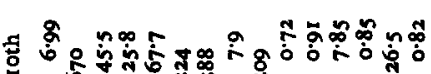

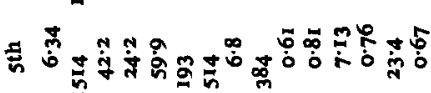

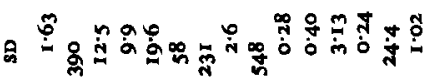

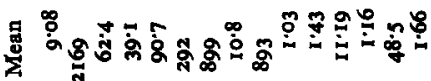

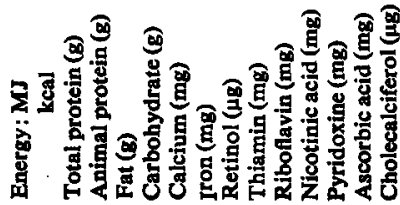

幽

논

จั

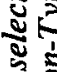

ริ

के

ธู้

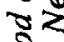

8.5

ริํํำ

2

ఏे

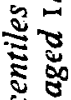

芒育

$2 \infty$

สิ

है จे

ธํำ

$\$$

है

To

จิ

ज.

苛

ते

క్

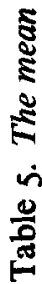

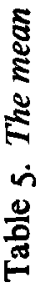

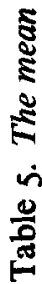

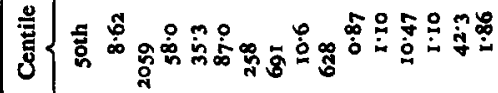

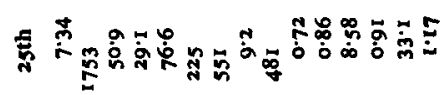

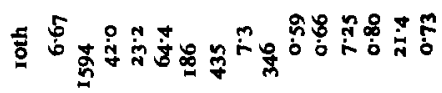

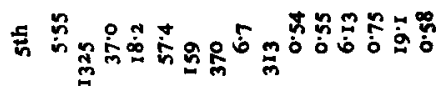

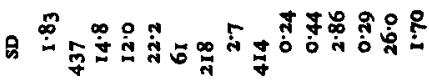

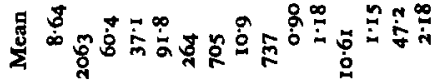

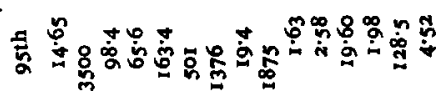

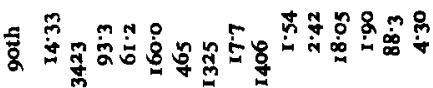

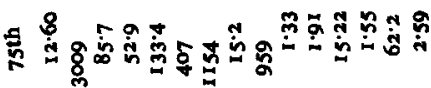

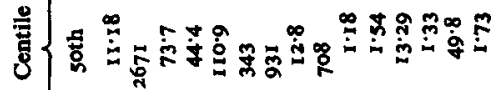

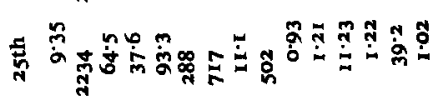

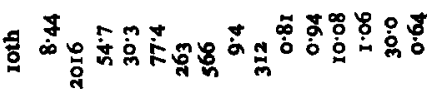

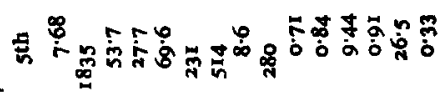

Q

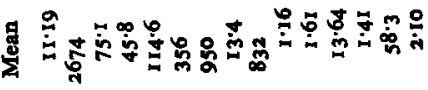

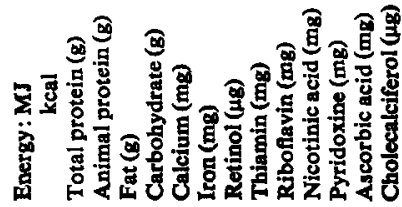




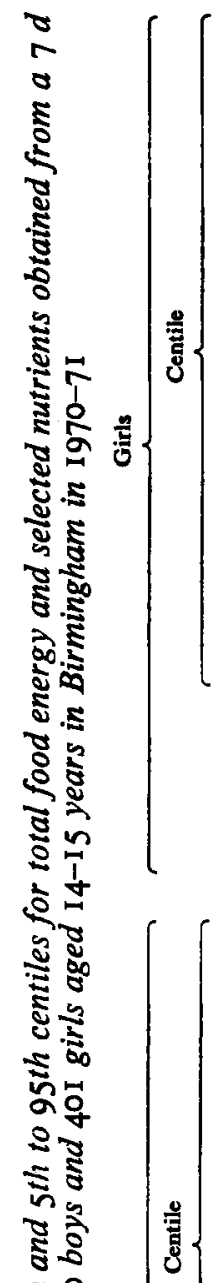

5

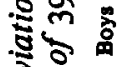

ป⿱艹

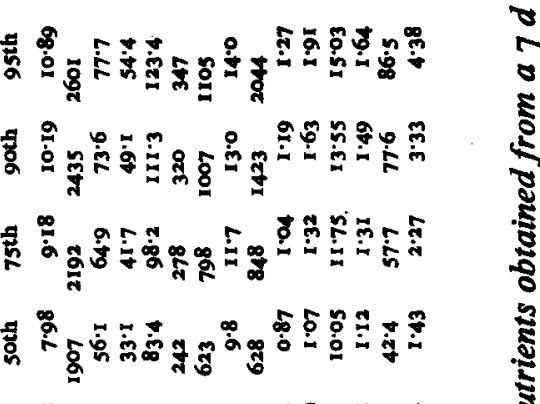

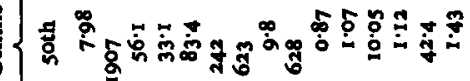

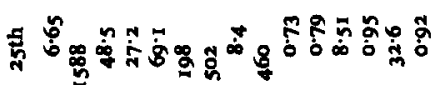

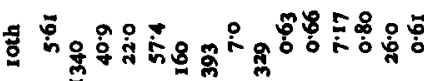

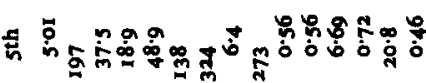

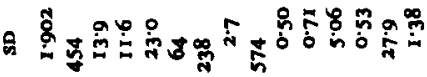

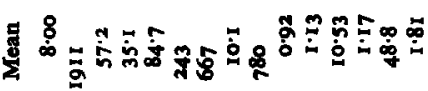

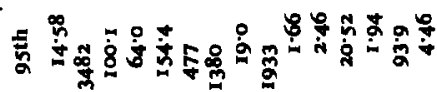

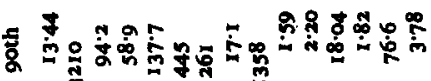

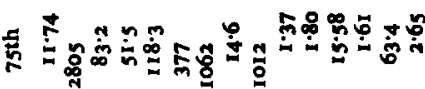

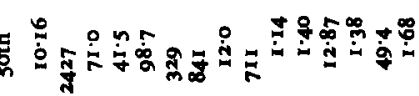

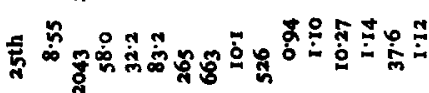

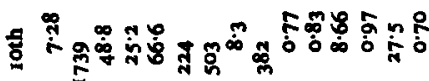

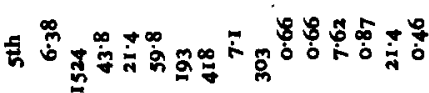

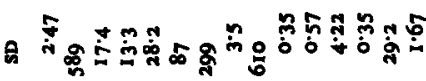

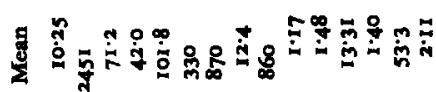

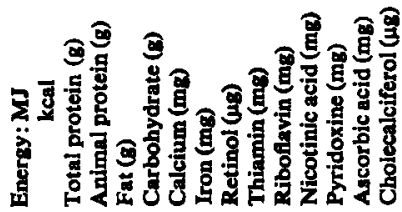

ริ

క్
है

ड़ํㅇ

पับ

है.

30

s.

造

ఫु

ธับ

อิ

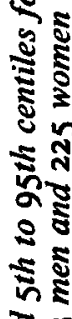

范

ह

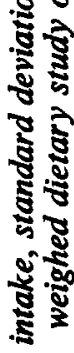

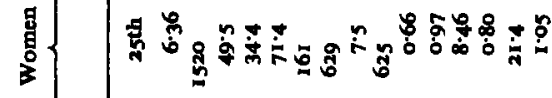

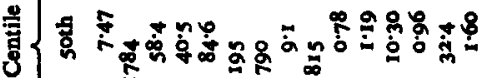

苛

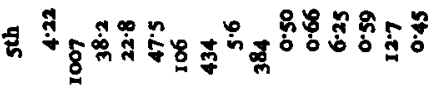

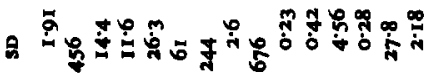

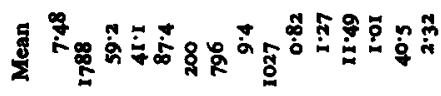

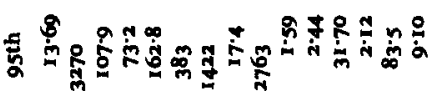

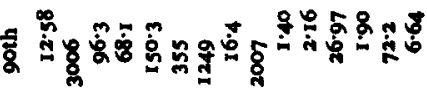

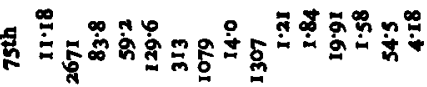

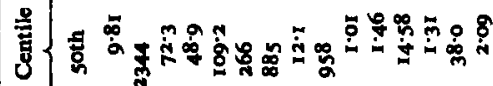

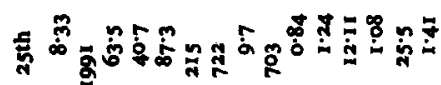

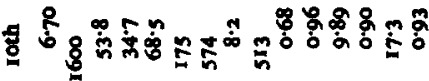

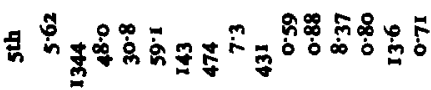

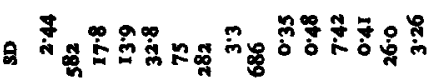

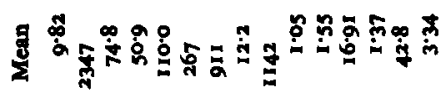

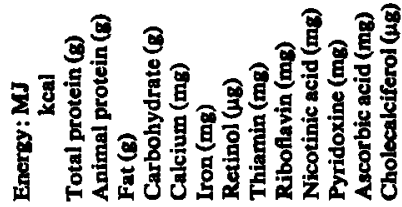




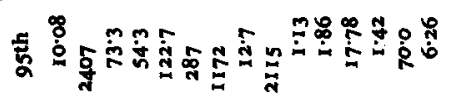

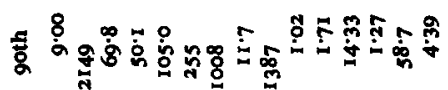

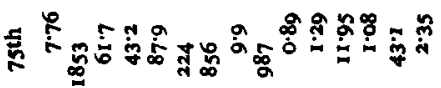

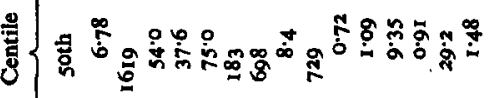

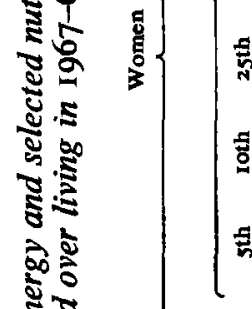

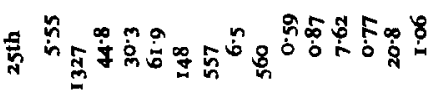

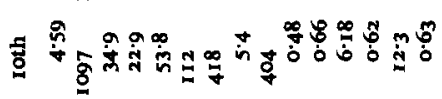

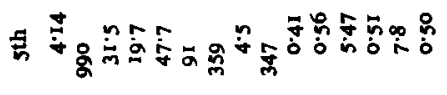

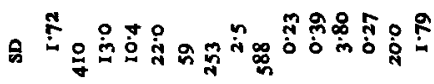

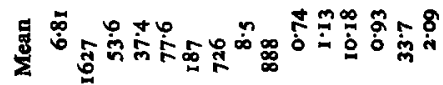

จ

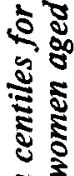

สัฐ

2

ถัฐ

เ

.

8

8

है

के

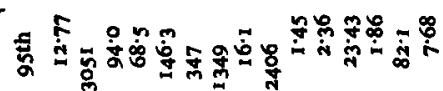

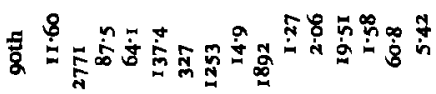

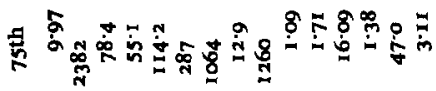

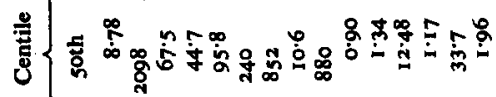

造

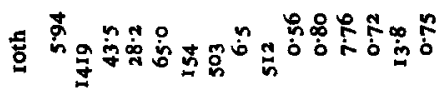

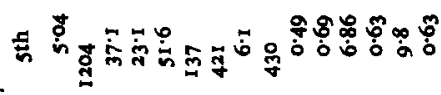

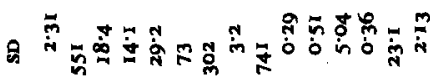

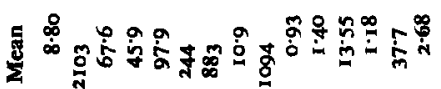

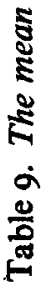

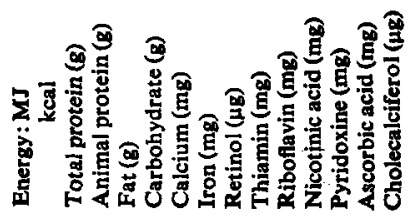


Smith et al. 1972; Lonergan et al. 1975). Many nutritionists have suggested that in an environment where the motor-car, television and domestic and industrial work-saving appliances are common, individual energy requirements are less than they were a decade or so ago. This implies that the recommended intakes for food energy were set too high in 1969. They have been reduced in a new report (Department of Health and Social Security, 1979).

\section{Difference in energy intakes between the sexes}

Sex differences in energy intake have been discussed by Durnin (1976). As expected, in these studies of schoolchildren and adults, mean energy intakes of men and boys were greater than those of women and girls of the same age. This difference between the sexes was allowed for above the age of II years in the Department of Health and Social Security (1969) recommendations but the results reported here showed that even in pre-schoolchildren from age 12 months onwards boys have higher energy intakes than girls of the same age. Widdowson (1947) and Black et al. (1976) also found that energy intakes of boys were larger than those of girls at this early age. The recommended daily amounts of energy for groups of people are now larger for males than for females from infancy onwards (Department of Health and Social Security, 1979).

\section{Nutrient intakes}

Recommendations for nutrient intakes were defined in the Department of Health and Social Security (1969) Report as amounts "which are sufficient or more than sufficient for the nutritional needs of practically all people in a healthy population'. The distributions of the selected nutrient intakes reported here showed that many individuals in the different groups were eating less than the amount recommended without any signs of malnutrition. In addition the 1969 recommended amounts either approximated to or were less than the mean of the frequency distributions of intakes. The findings suggest that a more practical definition of the recommended amount of a nutrient would be the average amount of the nutrient which should be provided per head in a group of healthy people if the needs of practically all members of the group are to be met. This definition was agreed by the Committee on Medical Aspects of Food Policy (Department of Health and Social Security, 1979).

The authors acknowledge gratefully the help of Area Medical Officers and Principal School medical officers in the places in which they worked at the time of the pre-school and schoolchildren surveys, of the General Medical Practitioners who co-operated in the survey of pregnant women and of the Senior Physicians in Geriatric Medicine who assessed clinically the participants in the surveys of elderly people. Not least, they wish to thank all the subjects who took part so willingly in the surveys.

\section{REFER EN CES}

Black, A. E., Billewicz, W. Z. \& Thomson, A. M. (1976). Br.J. Nutr. 35, 105.

Cook, J., Altman, D. G., Moore, D. M. C., Topp, S. G., Holland, W. W. \& Elliott, A. (I973). Br. J. prev. Soc. Med. 27,91.

Department of Health and Social Security (1969). Rep. Publ. Hlth. med. Subj. no. 120.

Department of Health and Social Security (1972). Rep. Hlth. Soc. Subj. no. 3.

Department of Health and Social Security (1975). Rep. Hlth. Soc. Subj. no. 10.

Department of Health and Social Security (1979). Rep. Hlth. Soc. Subj. no. 15.

Durnin, J. V. G. A. (1976). Proc. Nutr. Soc. 35, 145.

Durnin, J. V. G. A., Lonergan, M. E., Good, J. \& Ewan, A. (1974). Br.J. Nutr. 32, 169.

Durnin, J. V. G. A., Mclees, W. J., Yuill, S. A., Bushy, A. D., Gay, C. A. \& Blake, E. C. (I964). Proc. Nutr. Soc. 23, xiv. 


\section{Sylvia J. Darke, Molly M. Disselduff and G. P. Try}

Exton-Smith, A. N., Stanton, B. R., \& Windsor, A. C. M. (1972). Nutrition of Housebound Old People. London: King Edward's Hospital Fund for London.

Lonergan, M. E., Milne, J. S., Maule, M. M. \& Williamson, J. (1975). Br. J. Nutr. 34, 517.

Ministry of Health (1968). Rep. Pub. Hlth. med. Subj, no. I I8.

Stanton, B. R. \& Exton-Smith, A. N. (1970). A Longitudinal Study of the Diets of Elderly Women. London: King Edward's Hospital Fund for London.

Topp, S. G., Cook, J. \& Elliott, A. (1972). Br. J. prev. Soc. Med. 26, 106.

Widdowson, E. M. (1947). Spec. Rep. Ser. med. Res. Counc. no. 257. 